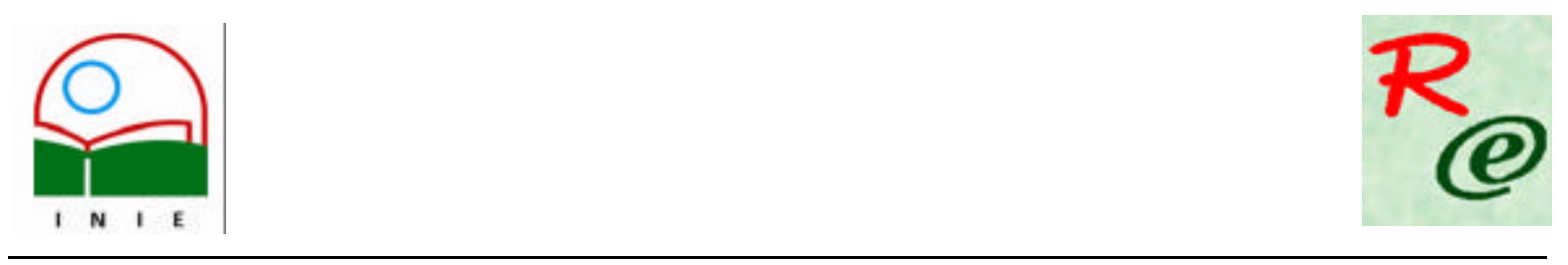

Actualidades Investigativas en Educación

Revista Electrónica publicada por el

Instituto de Investigación en Educación

Universidad de Costa Rica

ISSN 1409-4703

http://revista.inie.ucr.ac.cr

COSTA RICA

\title{
USING TASK-BASED INSTRUCTION IN AN ESP COURSE IN THE COMPUTER CENTER AT THE UNIVERSITY OF COSTA RICA
}

EL USO DE LA METODOLOGÍA BASADA EN TAREAS EN UN CURSO DE INGLÉS CON PROPÓSITOS ESPECÍFICOS EN EL CENTRO DE INFORMÁTICA DE LA UNIVERSIDAD

DE COSTA RICA

\author{
Volumen 9, Número 1 \\ pp. $1-25$
}

Este número se publicó el 30 de abril 2009

Patricia Córdoba Cubillo

César Navas Brenes

La revista está indexada en los directorios:

LATINDEX, REDALYC, IRESIE, CLASE, DIALNET, DOAJ, E-REVIST@S,

La revista está incluida en los sitios:

REDIE, RINACE, OEI, MAESTROTECA, PREAL, HUASCARAN, CLASCO 


\title{
USING TASK-BASED INSTRUCTION IN AN ESP COURSE IN THE COMPUTER CENTER AT THE UNIVERSITY OF COSTA RICA \\ EL USO DE LA METODOLOGÍA BASADA EN TAREAS EN UN CURSO DE INGLÉS CON PROPÓSITOS ESPECÍFICOS EN EL CENTRO DE INFORMÁTICA DE LA UNIVERSIDAD DE COSTA RICA
}

\author{
Patricia Córdoba Cubillo \\ César Navas Brenes²
}

\begin{abstract}
This article presents the advantages of using Task-based Learning to help learners from the Computer Center at the University of Costa Rica infer the rule of the superlative form of adjectives in Engish. This group of learners was taking an ESP course that was team taught by two instructors. The course lasted four months, and the instructors covered four different units. It is important to mention that the methodology based on tasks help learners pay more attention or concentrate more on meaning than Task -based language learning is an approach in which learners concentrate more on meaning than on form. By doing this, students perform different communicative tasks, which happen to be more meaningful because they are close to the learners' reality, instead of doing form based discrete exercises, which are usually decontextualized and meaningless because they do not see a reason to do them. In the lesson presented in this article, the Computer Center students were asked to express their own ideas, either orally or in a written mode, about the topic of the lesson, the superlative form of the adjectives in English.
\end{abstract}

Key words: ESP COURSE, LESSON, TASK-BASED LEARNING, LEARNERS, METHODOLOGIES, OUTCOME, TEACHING

Resumen: Este artículo tiene como propósito presentar las ventajas de usar la metodología basada en tareas (Task-based Learning) para ayudar a un grupo de estudiantes del Centro de Informática de la Universidad de Costa Rica a inferir la regla y uso de la forma superlativa de los adjetivos en inglés Estos estudiantes recibían un curso de inglés con propósitos específicos impartido por dos docentes de inglés. El curso tuvo una duración aproximada de cuatro meses y se cubrieron cuatro unidades. Es necesario señalar que la metodología basada en tareas ayuda a los y las estudiantes a concentrarse más en el significado que en la forma. Al hacer esto, los y las estudiantes llevan a cabo diferentes tareas comunicativas que tienen más significado porque se asemejan más a sus actividades cotidianas que los ejercicios gramaticales tradicionales, los cuales la mayoría de veces son descontextualizadas e insignificantes. En la sección que se presenta en este artículo, los y las estudiantes del Centro de Informática expresaron sus ideas, oralmente o por escrito del tema gramatical: la forma superlativa de los adjetivos en inglés.

Palabras clave: CURSO DE INGLÉS CON PROPÓSITOS ESPECÍFICOS, LECCIÓN, APRENDIZAJE BASADO EN TAREAS, ESTUDIANTES, METODOLOGÍAS, RESULTADO, ENSEÑANZA

\footnotetext{
'Magíster en la Enseñanza del Inglés como Lengua Extranjera; Licenciatura en Lingüística, Bachiller en Inglés, Profesora de Enseñanza Media en el ramo de Inglés, todos los títulos de la Universidad de Costa Rica. Profesora de la Escuela de Lenguas Modernas de la Universidad de Costa Rica. Dirección electrónica: pcordobac@gmail.com.

${ }^{2}$ Magíster en la Enseñanza del Inglés como Lengua Extranjera de la Universidad de Costa Rica. Bachiller en Inglés de la Universidad Internacional de las Américas. Profesor de la Escuela de Lenguas Modernas de la Universidad de Costa Rica. Dirección electrónica: cesarnavasb@gmail.com.
}

Artículo recibido: 10 de febrero, 2009

Aprobado: 2 de abril, 2009 


\section{Introduction}

This article presents the principles and advantages of using Task-based Learning (TBL) in an ESP environment. It also presents the contents of a sample lesson in which Task-based Learning (TBL) was favored to teach the superlative form of adjectives instead of traditional form-based methodologies. This lesson was designed for a group of six EFL learners taking an ESP (English for Specific Purpose) course in the Computer Center at the University of Costa Rica. The main objectives of this article are (a) to summarize the most important insights behind task-based language instruction, (b) to explain the different components of the task-based framework with the content of a sample lesson, and (c) to give some useful recommendations to English teachers who want to incorporate this approach in their ESP course programs.

\subsection{Review of the Literature}

Task-based language learning is an approach in which learners concentrate on meaning rather than form. That is, students carry out a group of communicative tasks instead of doing form-based discrete exercises. Students are expected to express their own ideas, either orally or in a written mode, about the topic of the lesson. These ideas should be based on the analysis of meaning derived from a communicative activity. Willis (1996, p. 101) explains that "within the TBL framework, tasks and texts combine to give students a rich exposure to language and also opportunities to use it themselves." Due to this, learners work on a certain grammar feature inductively with a series of tasks.

Before analyzing the framework behind Task-based learning, instructors must pay close attention to the notion of communicative task. Willis (1996, p. 28) has defined the term task as those "activities where the target language is used by the learner for a communicative purpose (goal) in order to achieve an outcome." Furthermore, for language learners to attain the objectives of a TBL task, it must fulfill certain characteristics, especially if it is part of an ESP course. First, the task should have an appropriate level of complexity and difficulty. Secondly, in an ESP context the primary goal of a task should reflect what learners need to do in real-life situations at the workplace (i.e. exchanging information, giving instructions or presenting an oral report). Besides, tasks must be based on authentic materials obtained from written or oral texts which have not been adapted to simplify their level of difficulty. In addition, Willis (1996, p.23) has pointed out that instructors should prepare communicative Volumen 9, Número 1, Año 2009, ISSN 1409-4703 
activities with "a suitable degree of intellectual and linguistic challenge and promote learners' language development as efficiently as possible." Also, tasks should include a given feature of language form for students to convey meaning. Some language features, for instance, may be how to use the passive voice, the comparative and superlative forms of adjectives, or the conditional sentences, among others.

Communicative TBL tasks should also have a clear outcome that is an observable behavior, which can be evaluated throughout the different phases of the TBL framework. This means that activities must have an effective exchange of oral or written data which can be done in pairs or small groups. However, the instructor may also lead a whole-class discussion of the students' findings obtained after the task cycle has been completed. Although several types of communicative tasks can be implemented by course designers, teachers should look for an integration of different language skills. In terms of Task-based instruction, Skehan (1998) states that

a task is an activity that satisfies the following criteria: meaning is primary, there is a goal that needs to be worked forward, the activity is outcomeevaluated and there is a real-world relationship. The syllabus designer, the teacher, or the student can choose tasks for the language classroom. Whoever it is, the decision maker needs to have information about the nature of the task, the requirements made by the task, and the potential outcomes of the task (in Celce-Murcia and Olshtain, 1998, p.189).

With the Task-based framework, there is a wide variety of open tasks with a clear objective. Learners do not necessarily focus on a particular grammar item; instead, they convey or exchange meaning before dealing with an outcome. At an advanced stage of the task cycle, learners will have the possibility to do language focus tasks that include consciousness-raising activities to think about language form and its use. Willis (1996, p. 2628) has listed some types of TBL tasks which can be implemented in an ESP context. Some of these tasks will be exemplified with activities students from the UCR Computer Center may perform. They are:

a. Listing: in this case, the instructor takes advantage of learners' prior knowledge on the topic to be developed. The outcome of this activity may be a list of concepts that the instructor collects from students.

b. Ranking items: students rank their most important work duties where the target language is used. 
c. Comparing or contrasting items: in a computer lab, for instance, learners may make comparisons of the advantages and disadvantages of computer hardware or software. A whole-class discussion about these advantages and disadvantages may be carried out as the outcome of this activity.

d. Problem-solving activities: in this task, students may give advice on how to solve common problems at the workplace. For instance, if students talk about how to install some computer equipment, the evaluated outcome could consist of an efficient way to do this task correctly.

e. Sharing personal experiences: these open tasks consist of an exchange of anecdotes among students. Telling anecdotes is a fluency-building activity in which learners talk about their experiences at the workplace. Since this speaking task is not goal-oriented because through it learners increase their fluency, teachers should include in their classrooms other types of tasks such as the ones already mentioned.

f. Creative tasks: these challenging activities, which usually consist of small-group project presentations, that in turn become the outcome of the task, require a higher level of preparation and integration of skills.

As pointed out before, task-based instruction is an approach that focuses on the notion of task as a primary component of language use. D. Willis and J. Willis (in Carter and Nunan, 2001, p. 174) have stated that "one feature of TBL, therefore, is that learners carrying out a task are free to use any language they can to achieve the outcome: language forms are not prescribed in advance." These authors have explained that individuals are enabled to react to new language input and use it to produce meaning in real-life interaction (p.174).

Some criticism, on the other hand, has emerged in regard to the internalization of grammar structures with TBL methodologies. D. Willis and J. Willis (in Carter and Nunan, 2001 , p. 174) stated that the study of grammar should be given more importance in communicative approaches in order to achieve acquisition of the target language. Even though TBL instruction does not focus on the direct study of language form at the early stages of the framework, learners must reflect on specific grammar features with the aid of consciousness-raising activities. This type of activities helps learners become aware of, identify and process specific language features from the task text. It is recommended to provide students with authentic contexts, so that they have the opportunity to ask about other similar features, to analyze its usage, and to do additional practice. Furthermore, teachers Volumen 9, Número 1, Año 2009, ISSN 1409-4703 
should recycle content in subsequent sessions because if students fail at increasing awareness of such particular language item being taught, fluency, not accuracy, may be favored.

\subsection{Task components}

When designing a task-based lesson, its components or stages must be taken into consideration since they are the ones that lead students to be able to do the main task of the lesson. Brown (1994, p. 83) has explained that

Task-based learning is not a new method. Rather, it simple puts task at the center of one's methodological focus. It views the learning process as a set of communicative tasks that are directly linked to the curricular goals they serve, and the purposes of which extend beyond the practice of language for its own sake. Research on taskbased learning attempts to identify types of tasks that enhance learning (for example, open-ended, structured, teacher-fronted, small group, pair work) and to define taskspecific learner factors (roles, proficiency levels, styles), teacher roles, and other variables that contribute to a successful achievement of goals.

With this task-based lesson, learners must go through a series of pedagogical tasks within a well-structured framework that contains a pre-task, a task-cycle, and the language focus. In an ESP context, the learners' primary goal is to be able to perform target language tasks for effective real-life communication at the workplace.

Ellis (2006, p. 2) cites several authors that propose various designs of frameworks; however, they all coincide in three principal stages or phases as he shows in the following figure: 


\begin{tabular}{|c|c|}
\hline Phase & Examples of options \\
\hline A. Pre-task & $\begin{array}{l}\begin{array}{l}{ }^{*} \text { Framing the activity (e.g. establishing the outcome of } \\
\text { the } \\
\text { * }\end{array} \\
\text { * Doing a similar task }\end{array}$ \\
\hline B. During task & * Number of participants \\
\hline C. Post-task & \begin{tabular}{|lrr}
$*$ & Learner & report \\
$*$ & & Consciousness-raising \\
$*$
\end{tabular} \\
\hline
\end{tabular}

Fig. 1. A framework for designing task-based lessons

Such distribution of phases reflects how the lesson will be developed. According to Ellis (p. 2, 2006), the first phase in the framework shown in Figure 1 is the 'pre-task' that includes the various activities that teachers and students can undertake before beginning the task. Some of these activities may be asking and answering questions, reading a passage related to the topic, listening to an audio segment or watching a video. The second phase, the 'during task' phase, centers around the task itself and affords various instructional options, including whether students are required to operate under time-pressure or not. The final phase is 'post-task' and involves procedures for following-up on the task performance. Only the 'during task' phase is obligatory in task-based teaching. Thus, minimally, a task-based lesson should consist of only one task performed by the students. Options selected from the 'pre-task' or 'post-task' phases are non-obligatory but can serve a crucial role in ensuring that the task performance is maximally effective for language development.

Another TBL framework is the one presented by Willis (1998). Her first two phases are similar to Ellis'. The language focus is the equivalent to Ellis' post task shown in Figure 2.

\section{TASK-BASED FRAMEWORK}

\section{INTRODUCTION TO TOPIC AND TASK}

Teacher explores the topic with the class, highlights useful words and phrases, and helps learners understand task instructions and prepare for [it]. Learners may hear [sic] a recording of others doing a similar task, or read part of a text as lead in to a task. 


\section{PRE-TASK PHASE}

\section{TASK CYCLE}

\begin{tabular}{|c|c|c|}
\hline TASK & PLANNING & REPORT \\
\hline $\begin{array}{l}\text { Students do the task, in pairs } \\
\text { or small groups. Teacher } \\
\text { monitors from a distance, } \\
\text { encouraging all attempts at } \\
\text { communication, not } \\
\text { correcting. Since this situation } \\
\text { has a "private" feel, students } \\
\text { feel free to experiment. } \\
\text { Mistakes don't matter. }\end{array}$ & $\begin{array}{l}\text { Students prepare to report to the } \\
\text { whole class (orally or in writing) } \\
\text { how they did the task, what they } \\
\text { decided or discovered. Since the } \\
\text { report stage is public, students } \\
\text { will naturally want to be } \\
\text { accurate, so the teacher stands } \\
\text { by to give language advice. }\end{array}$ & $\begin{array}{l}\text { Some groups present their } \\
\text { reports to the class, or } \\
\text { exchange written reports, and } \\
\text { compare results. Teacher acts } \\
\text { as a chairperson, and then } \\
\text { comments on the content of } \\
\text { the reports. }\end{array}$ \\
\hline
\end{tabular}

\section{LANGUAGE FOCUS}

\begin{tabular}{|c|c|}
\hline ANALYSIS & PRACTICE \\
\hline $\begin{array}{l}\text { Students examine and then discuss specific } \\
\text { features of the text or transcript of the } \\
\text { recording. They can enter new words, } \\
\text { phrases and patterns in vocabulary books. }\end{array}$ & $\begin{array}{l}\text { Teacher conducts practice of new words, phrases, } \\
\text { and patterns occurring in the data, either during or } \\
\text { after the Analysis. }\end{array}$ \\
\hline
\end{tabular}

Fig. 2. A framework for designing task -based lessons (Willis, 1996)

The frameworks shown above can be adapted to suit learners' needs. The frameworks help teachers have a fowing sequence in their lessons because each stage prepares the ground for the next. It is important to point out that the pretask stage is the shortest stage in the framework. It should last from five to twenty minutes, depending on how familiar learners are with the topic and the type of task. The goal of pre-task activities is to explore topic language and involve all learners actively and create interest in doing a task on the chosen topic (Willis, pp. 41- 43, 1996). The task phase is the most important one in the framework. In this phase, learners use their knowledge to accomplish the task. Finally, in the language focus or post-task stage students evaluate what they have learned in the previous stages. Volumen 9, Número 1, Año 2009, ISSN 1409-4703 
They can do this by means of a group discussion, solving exercises similar to the ones they did in the task stage, or writing a short report on the issue.

As Willis (1998) stated, TBL offers a change from the grammar practice routines through which many learners have previously failed to learn to communicate. It encourages learners to experiment with whatever English they can recall, to try things out without fear of failure and public correction, and to take active control of their own learning, both in and outside class, and this is what really matters in teaching a task-based lesson.

\section{Methodology}

\subsection{Course description}

Intermediate English for the Computer Center Personnel was an ESP course team taught by the authors and designed to meet the needs of a group of workers (systems engineers, computer programmers, computer and telecommunications technicians, secretaries, and administrative workers) from the Computer Center at the University of Costa Rica. This ESP course was aimed at helping these personnel with their language skills $b$ perform better in their workplace. In other words, it would help the learners improve their listening, speaking, reading, and writing skills to carry out different tasks at their workplace. This learner-centered ESP course emphasized the integration of the four skills: listening, speaking, reading, and writing along the teaching-learning process. It also promoted the students' awareness and application of their learning strategies to perform better in the learning of the target language. Students were provided with the appropriate materials and tasks to meet their wants, expectations, and needs at their workplace.

The general objectives of the course are described in Table 1.

\section{Table 1}

\section{General objectives}

\begin{tabular}{|l|}
\hline Help the \\
Computer \\
Center \\
personnel \\
\hline
\end{tabular}




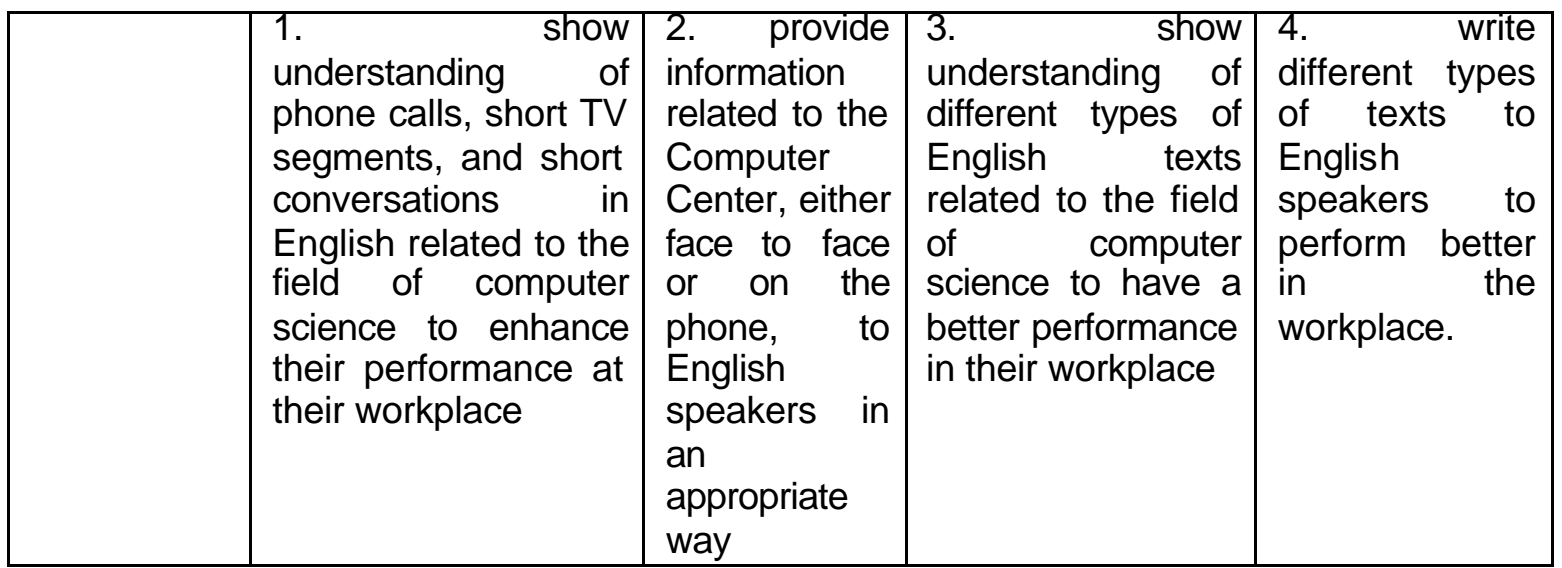

Table 2 describes the specific objectives of the course.

Table 2

\section{Specific objectives}

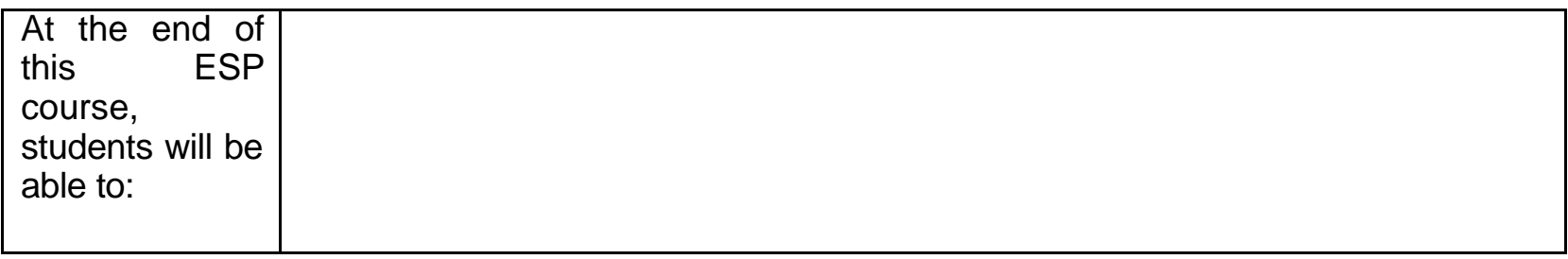

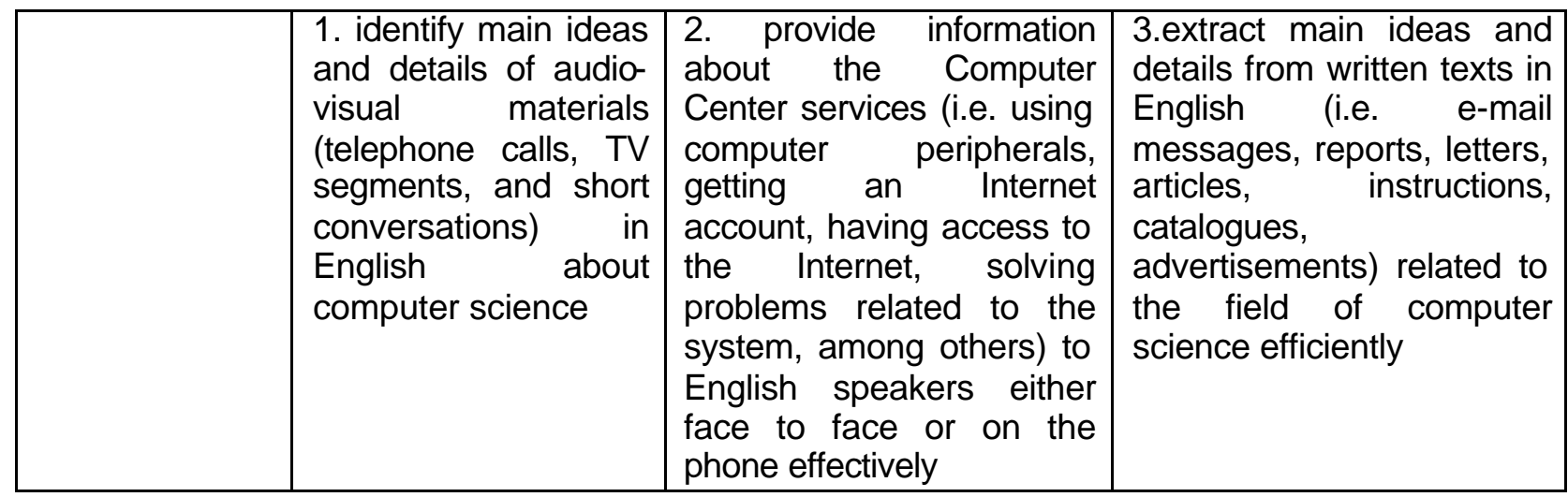

\subsection{Contents of the course}

The course was divided into four units; each addressed students' lacks, needs and wants. Unit 1: Becoming Acquainted with Each Other was designed to help learners know their classmates better, the objectives of the course and the instructors. Unit 2: At the 
Computer Center helped learners get familiar with the sections of the Computer Center. Unit 3: Computer Technology: Its Applications was devoted to technology and the way it was applied at their workplace. Finally, Unit 4: Surfing the Net dealt with the language needed to talk about the Internet and its applications to perform better at the workplace.

\subsection{Participants}

The target population consisted of 6 students, three male and three female. Their ages ranged from 20 to 54 . Two were systems engineers; others were computer technicians, and two worked as secretaries. Their academic backgrounds were very varied, as well. Two have university degrees such as Master's and Ph.Ds, and the other four are technicians graduated from technical or vocational schools. Their proficiency level was also very different. Two were high intermediate; two were intermediate, and the last two were high beginners. They met two times a week for 1 hour and 45 minutes.

Table 3 shows the needs, lacks and wants of the English language that the students from the Computer Center had before the course started. This information was collected through a needs analysis implemented before the course was designed. The learners were interviewed and given a written test to determine their weaknesses and strengths as well as needs and wants in relation to the target language in areas such as vocabulary, syntactic structures, oral and written skills, among others.

\section{Table 3}

Needs, wants and lacks of the students in the course Intermediate English for the Computer Center Personnel

\begin{tabular}{|l|ll|l|}
\hline \multicolumn{2}{|c|}{ Needs } & \multicolumn{1}{c|}{ Wants } & \multicolumn{1}{c|}{ Lacks } \\
\hline $\begin{array}{l}\text { Develop basic conversation skills in } \\
\text { order to answer phone calls or assist } \\
\text { visitors }\end{array}$ & $\begin{array}{l}\text { Improve } \\
\text { pronunciation }\end{array}$ & $\begin{array}{l}\text { English grammar structures: } \\
\text { question formation, subject- } \\
\text { verb agreement, verb tenses } \\
\text { (present, past, future) }\end{array}$ \\
\hline $\begin{array}{l}\text { Improve basic writing principles to } \\
\text { write and/or answer letters and e-mail } \\
\text { messages }\end{array}$ & $\begin{array}{l}\text { Improve listening skills } \\
\text { fronunciation endings, consonant } \\
\text { sounds (v/ b, sh / ch, and th } \\
\text { sounds) }\end{array}$ \\
\hline Develop basic listening skills & $\begin{array}{l}\text { Increase } \\
\text { vocabulary }\end{array}$ & technical \\
\hline
\end{tabular}




\subsection{Sample Lesson}

The sample lesson presented in this article belonged to Unit 4: Surfing the Net. One of the objectives of this unit was to teach the students the superlative form of adjectives in English using the Task-based approach. Following the frameworks presented in Figures 1 and 2, this lesson contains the pre-task, the task and the posttask stages. In the pre-task, the students had to read a series of advertisements taken from magazines related to computers and computer equipment or peripherals to help them to do the task. The task consisted of a True-False exercise in which the learners, based on some underlined information, had to discriminate if the information was true or false. In this task, the students had to put into practice what they had learned in the pre-task because they had to infer the rules of the superlative form of adjectives in English. The post-task stage helped learners consolidate their knowledge in regard to the rules of the use of the superlative form of adjectives in English since they had to apply them in different sentences. This last stage also raised the learners' awareness in relation to the superlative form of adjectives. Following is the lesson plan of this sample lesson. 


\begin{tabular}{|c|c|c|c|c|c|}
\hline OBJECTIVES & $\begin{array}{c}\text { LANGUAGE / } \\
\text { GRAMMAR }\end{array}$ & ACTIVITIES & MATERIALES & EVALUATION & TIME \\
\hline $\begin{array}{l}\text { 1. Warm-up } \\
\text { Students will be able } \\
\text { to use what they } \\
\text { learned in the } \\
\text { previous lesson in } \\
\text { new situation. }\end{array}$ & $\begin{array}{l}\text { - Present simple } \\
-\quad \text { Comparative } \\
\text { adjectives } \\
\text { - Vocabulary related } \\
\text { to computer science }\end{array}$ & $\begin{array}{l}\text { A. Students look for a card } \\
\text { posted on the wall and pick it. } \\
\text { B. Students ask classmates for } \\
\text { information on how to use } \\
\text { certain pieces of equipment. } \\
\text { C. Students answer questions. }\end{array}$ & $\begin{array}{l}\text { - Slips of paper } \\
\text { - Students' handouts }\end{array}$ & $\begin{array}{l}\text { Teachers give feedback on } \\
\text { grammar and pronunciation } \\
\text { errors. }\end{array}$ & $20^{\prime}$ \\
\hline $\begin{array}{l}\text { 2. Pre-reading } \\
\text { Buying New } \\
\text { Computer } \\
\text { Equipment } \\
\text { Students will } \\
\text { brainstorm in regard } \\
\text { to different } \\
\text { characteristics of } \\
\text { computer equipment. }\end{array}$ & $\begin{array}{l}\text { - Students' own } \\
\text { criteria }\end{array}$ & $\begin{array}{l}\text { A. Students write words / } \\
\text { phrases related to computer } \\
\text { equipment on strips of paper. } \\
\text { B. Students post the slips of } \\
\text { paper with information on a } \\
\text { computer. } \\
\text { C. Students read the } \\
\text { information on the slips of } \\
\text { paper. } \\
\text { D. Students write words or } \\
\text { phrases on their handouts. }\end{array}$ & $\begin{array}{l}\text { - Students' handouts } \\
\text { - Slips of paper } \\
\text { - Markers }\end{array}$ & $\begin{array}{l}\text { Teachers give feedback on } \\
\text { pronunciation errors. }\end{array}$ & $15^{\prime}$ \\
\hline $\begin{array}{l}\text { 3. Reading Task } \\
\text { Which Computer is } \\
\text { the Best? }\end{array}$ & $\begin{array}{l}\text {-Superlative forms } \\
\text { - Vocabulary related } \\
\text { to computer science }\end{array}$ & $\begin{array}{l}\text { Individual Work } \\
\text { Students read some } \\
\text { vocabulary words individually. }\end{array}$ & - Students' hand outs & $\begin{array}{l}\text { Teachers } \\
\text { related torify questions } \\
\text { meaning. }\end{array}$ & $10^{\prime}$ \\
\hline $\begin{array}{l}\text { 3.1 Students will } \\
\text { become familiar with } \\
\text { vocabulary related to } \\
\text { some computer ads. } \\
\text { 3.2 Students will be } \\
\text { able to scan different } \\
\text { computer ads to look } \\
\text { for information. }\end{array}$ & $\begin{array}{l}\text {-Superlative forms } \\
\text { - Vocabulary related } \\
\text { to computer science }\end{array}$ & $\begin{array}{l}\text { A. Individually, learners read } \\
\text { the ads and answer the } \\
\text { questions. } \\
\text { B. Students check answers. } \\
\text { with a partner. } \\
\text { C. Students share answers } \\
\text { with the rest of the class. }\end{array}$ & & $\begin{array}{l}\text { Teachers give feedback on } \\
\text { grammar and pronunciation } \\
\text { errors. }\end{array}$ & $20^{\prime}$ \\
\hline
\end{tabular}

Volumen 9, Número 1, Año 2009, ISSN 1409-4703 


\begin{tabular}{|c|c|c|c|c|c|}
\hline $\begin{array}{l}\text { 4. Learning } \\
\text { Grammar Inductively } \\
4.1 \text { Students will } \\
\text { become aware of the } \\
\text { use of the superlative } \\
\text { adjectives by } \\
\text { discriminating true for } \\
\text { false statements. }\end{array}$ & -Same as above & $\begin{array}{l}\text { A. Individually, students read } \\
\text { the statements. } \\
\text { B. Students go over the three } \\
\text { ads and write True or False } \\
\text { depending on the information. } \\
\text { C. Students share answers } \\
\text { with the rest of the class. } \\
\end{array}$ & $\begin{array}{l}\text { - Students' handouts } \\
\text {-Magazine ads }\end{array}$ & $\begin{array}{l}\text {-Teachers call the students' } \\
\text { attention in regard to } \\
\text { grammar, pronunciation, and } \\
\text { vocabulary problems. }\end{array}$ & $10^{\prime}$ \\
\hline $\begin{array}{l}\text { 4.2 Students will infer } \\
\text { the rule of the usage } \\
\text { of the superlative form } \\
\text { of adjective. }\end{array}$ & & $\begin{array}{l}\text { A. Individually, students } \\
\text { answer a set of questions } \\
\text { regarding the rules of the } \\
\text { superlative form. } \\
\text { B. Students share answers } \\
\text { using the superlative form of } \\
\text { adjectives with the rest of the } \\
\text { class. }\end{array}$ & & & $10^{\prime}$ \\
\hline \multirow[t]{2}{*}{$\begin{array}{l}\text { 5. Practicing } \\
\text { Grammar } \\
\text { Students will be able } \\
\text { to complete a series } \\
\text { of sentences with the } \\
\text { correct superlative } \\
\text { form of the adjective } \\
\text { in parentheses. }\end{array}$} & -Same as above & $\begin{array}{l}\text { A. Individually, students } \\
\text { complete the mini- } \\
\text { conversations with the correct } \\
\text { superlative form of the } \\
\text { adjective in parentheses. } \\
\text { B. Students share answers } \\
\text { with the rest of the class. }\end{array}$ & - Students' handouts & $\begin{array}{l}\text { Teachers give feedback on } \\
\text { grammar and pronunciation } \\
\text { errors. }\end{array}$ & $10^{\prime}$ \\
\hline & & $\begin{array}{l}\text { Homework: Read the } \\
\text { grammar practice in the post } \\
\text { task and do it. }\end{array}$ & & & \\
\hline
\end{tabular}


WARM-UP ACTIVITY

\section{GIVING INSTRUCTIONS AND ADVICE}

A. Look around the class and take one of the cards.
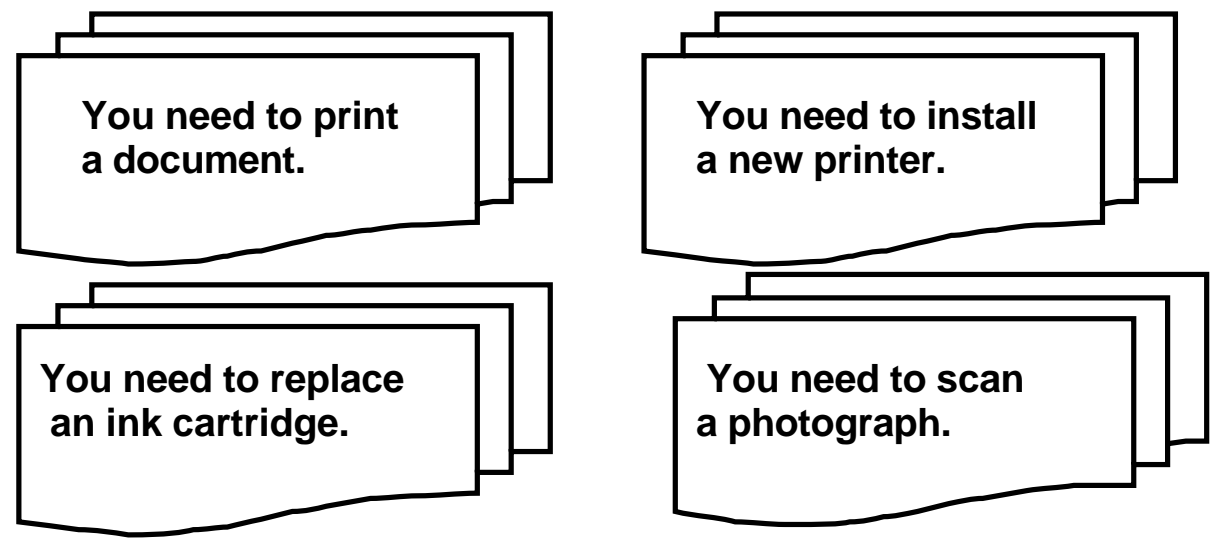

B. Ask classmates for information on how to use a certain piece of equipment. Use the language chart below.

\section{Useful language: Commands}

Don't forget to turn the printer on.

Remember to place the document facedown.

Make sure to load the printer with enough paper.

Try not to drop the mouse.

Be sure to buy the correct ink cartridge for your printer.

\section{COMMUNICATION STRATEGIES}

\section{QUESTIONS AND ANSWERS}

A: I'm sorry! I didn't get it. Can you repeat that please?

B: Sure, no problem at all.

A: Do you want me to repeat that again?

B: Yes, please.

A: I don't understand. Say that again, please!

B: Sure, no problem!

A: Excuse me, did you say facedown?

B: Exactly!

A: Is it clear now?

B: Yes, thank you!

A: You're welcome!

A: So, do I press this button?

B: That's right! 


\section{SUPERLATIVE FORM}

\section{BUYING NEW COMPUTER EQUIPMENT}

\section{PRE-TASK \\ BRAINSTORMING}

A. Individual Work.

Imagine you are going to buy a new computer.

What aspects do you take into account before buying a new personal computer?

Write those characteristics on the arrows next to the picture below.

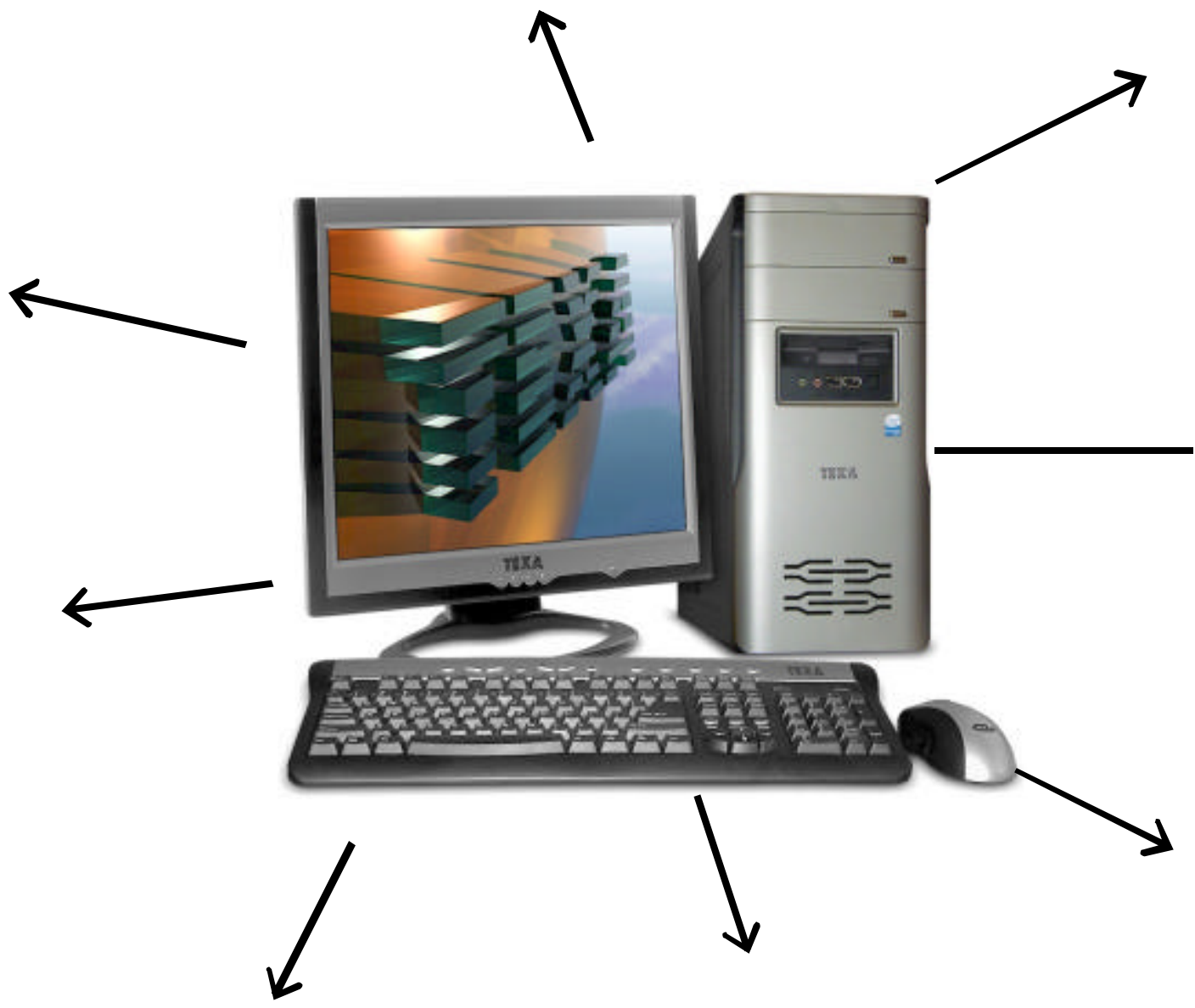

Picture retrieved from: www.apidemexico.com.mx 


\section{READING TASK}

\section{COMPUTER ADVERTISEMENTS}

I. Read the following explanation and study the vocabulary words given.

Computer ads contain lots of information with different choices for customers. They always present the latest and most sophisticated computer equipment.

Vocabulary words

1. mandatory: obligatory

2. pipe dream: a fantastic idea or hope

3. peak: maximum

4. pinnacle: the best

5. to boost: to increase

6. snap: easy

7. business lease: monthly payment business should pay for some service or equipment

\section{Reading Comprehension}

\section{Individual Work}

The ads you are about to read are found in computer magazines.

Ads taken from PCMAGAZINE, 2001 


\section{Advertisement \#1}

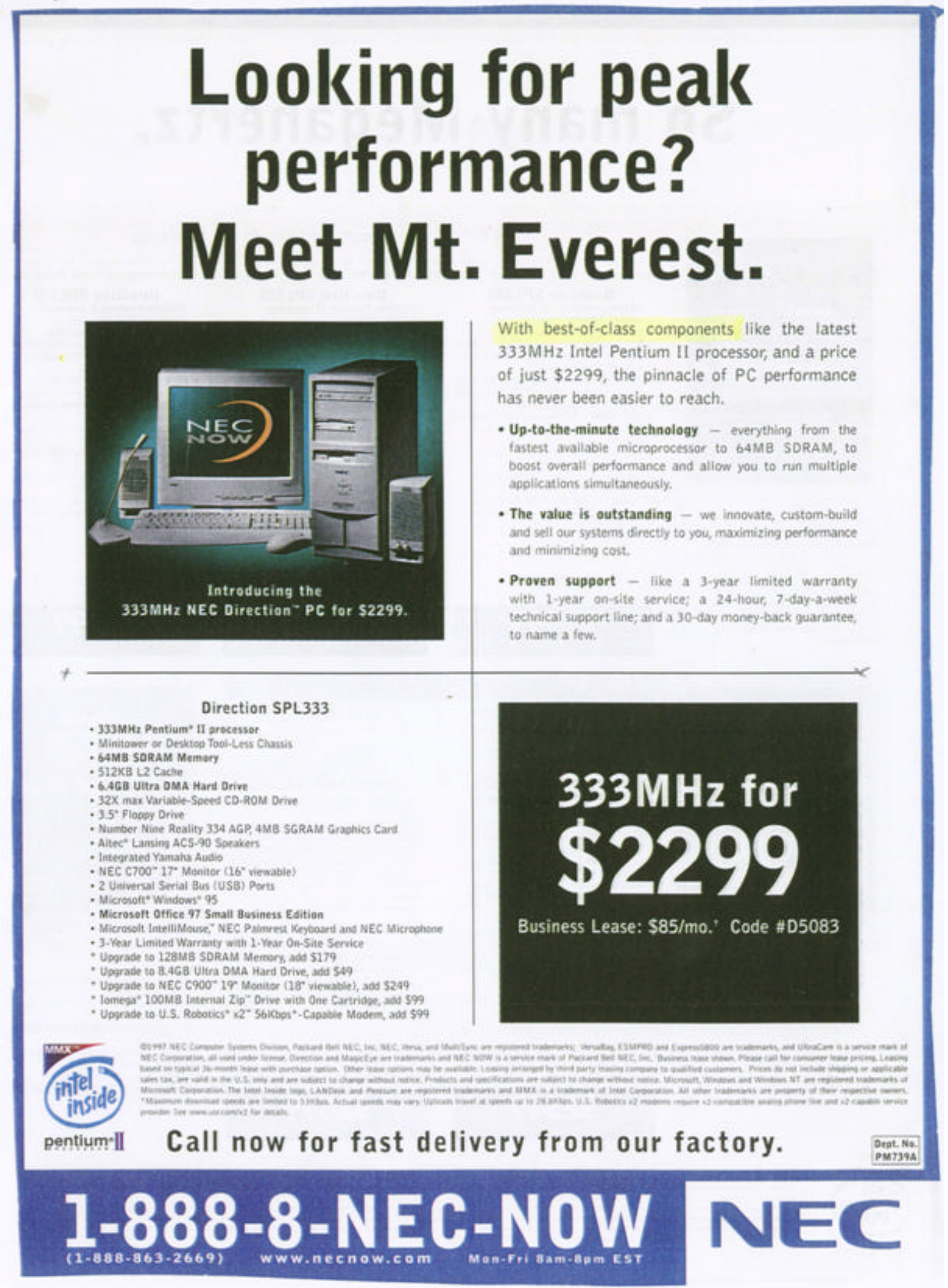




\section{Advertisement \#2}

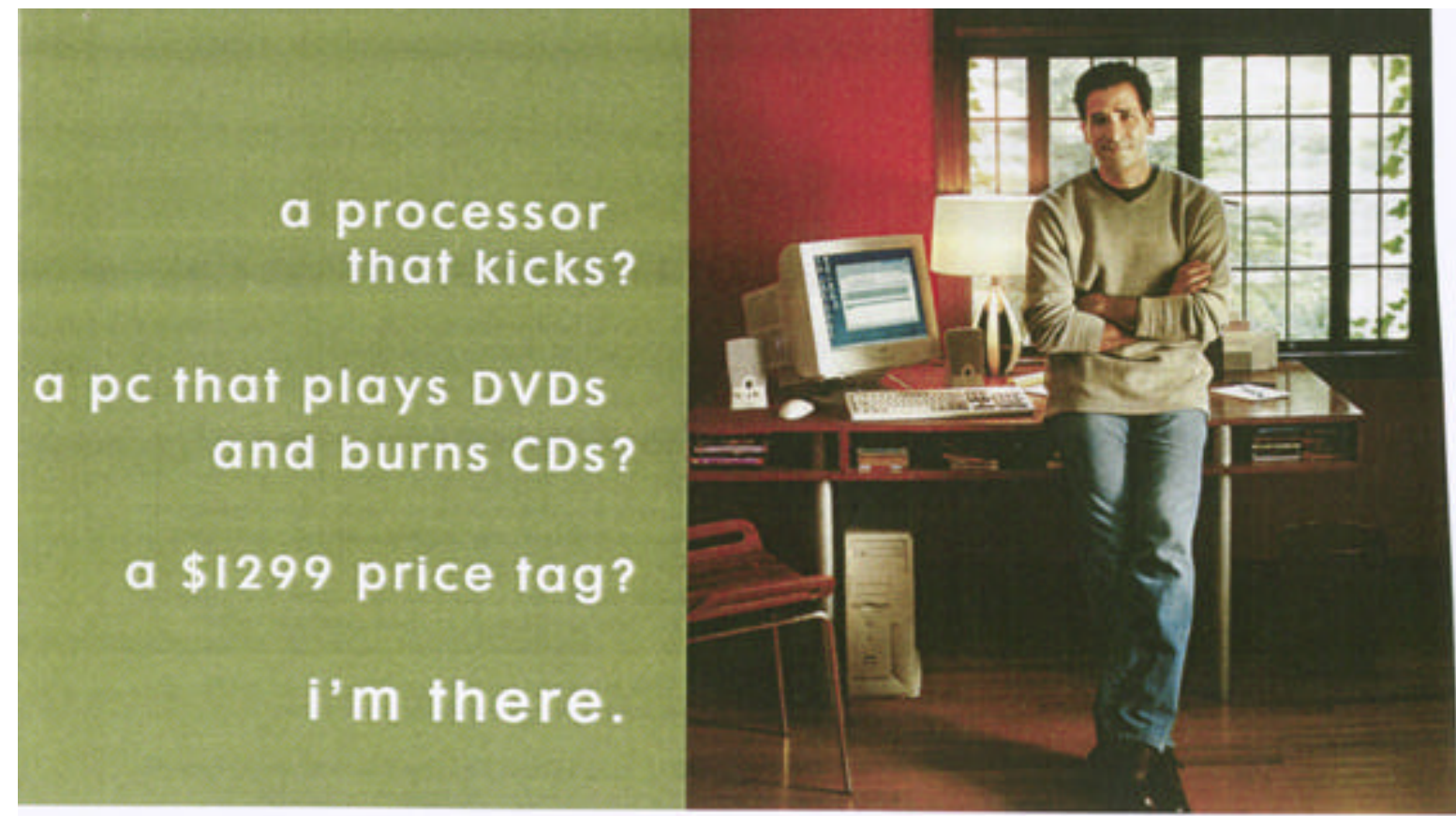

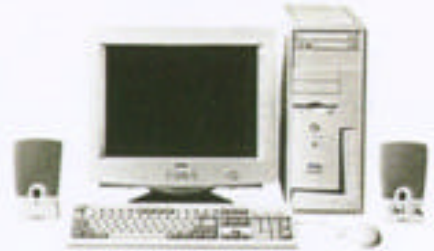

DELL" DIMENSION" 41005ente

Advanced Performance, Smart Value

- Intei" Pantium" il Processor ar 1GH.

- gamB SORAM al 13amser

- 20Ga' Uatra ATAN100 Hard Drive 17200 aPM

- $17^{*}\left(16.0^{*}\right.$ via) Eno Monitor

- 16Me ATI Rage" Pro

- NEW axu4X32X Max CD-FWiDDD Combo Drivi

- Sa Livel Value Digital * harmyokandon'Speakews

- sax Capabie' PCi Telephony Modem

- MS* Works Suite 2001 - MS* Windones" Me

- 3Yr Limited Warranty - 1.Y. At At Home Service

- 1 Year of DeliNet " by MSN" internet Access" included

$\$ 12990$

ASK U5 AGOUT NO PAYMENTSS FOR 90 DAYS

\section{A super-fast, feature-rich PC for just $\$ 1299$ ?} That's a classic "no-brainer"

It doesn't take too much arm twisting. The Dell" Dimansion" 4100 desktop with a fast intel" Pentium " III processor at $1 \mathrm{GHz}$ and a $\mathrm{CD}$-RW. DVO combination drive makes computing a snap. From crunching numbers to piaving your favorite movies to burning your top tunes. And it costs just \$1299. Plus, it's backed by Dell's award-winning around-the-clock service and support. Speed and cool features at a price you can afford-another way Dell4me- is helping you get what you're looking for, After all, at just \$1299, it doesn't take a rocket scientist to decide whether to get one of these babies. Order by phone or visit Dell online today.

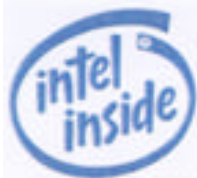

pentium*/I!

DeLl4me。com contact us today

Includes Windows Millennium Edition - the home version of the world's favorite software. 


\section{Advertisement \#3}

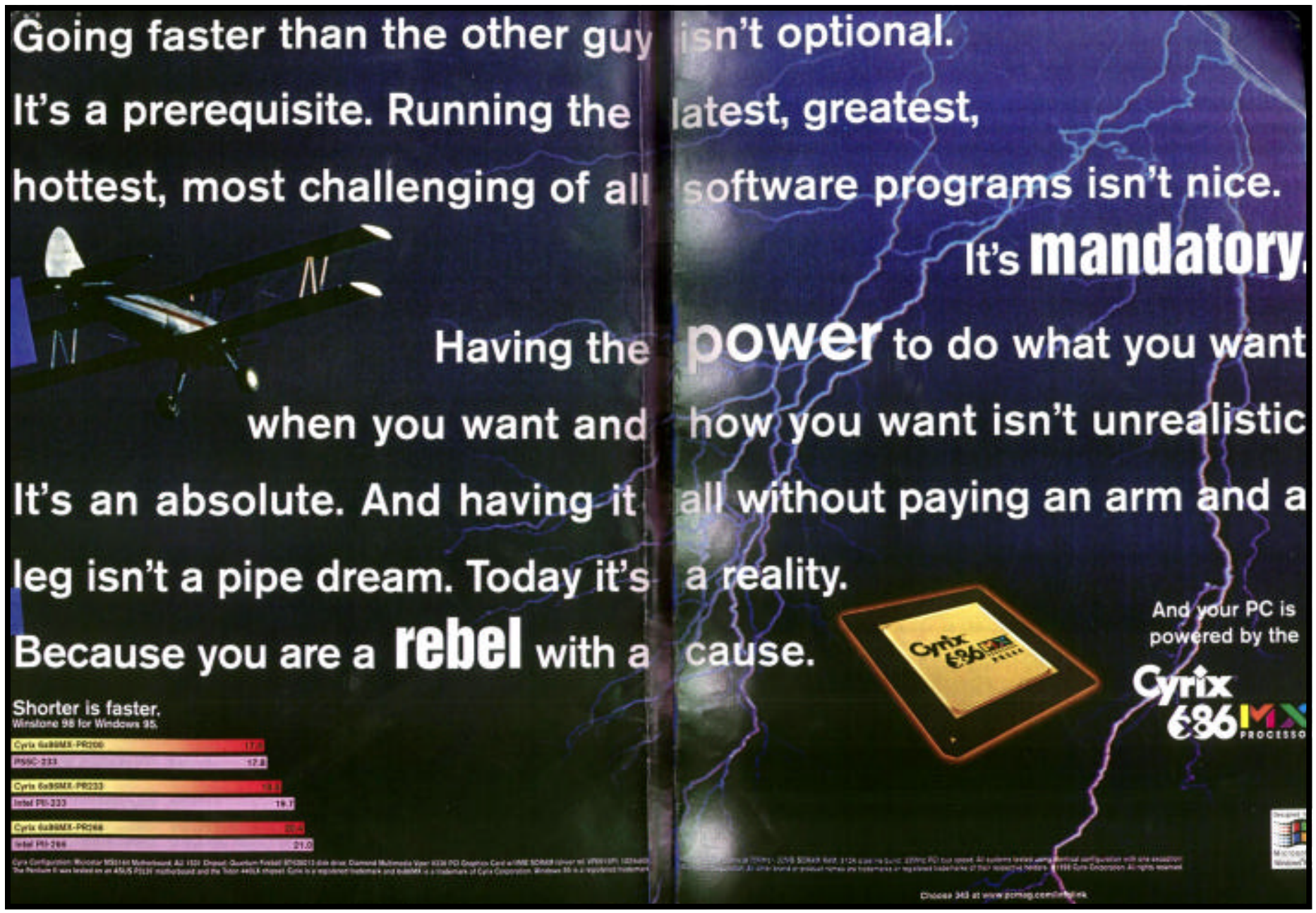




\section{A. You want to buy some computer equipment. Read the following statements, and answer these questions.}

1. You want to burn some CDs. Which computer should you buy?

2. You need to buy a computer with the latest processor. Which PC should you buy?

3. You need a new computer in your office, but you don't have all the money for it. Which computer seems the best option for your office?

4. You want a computer with good speakers. Which do you think are better quality, Altec or harman/kardon speakers?

5. Some people have told you that Microsoft is an excellent brand. You want to buy a new processor. Which Microsoft processor are they advertising?

B. Share your answers with another partner.

C. Be ready to discuss your answers with the rest of the class. 


\section{Individual Work}

\section{A. Read the following sentences about computers. Then, circle True or False according to the information given.}

\section{DESCRIBING DIFFERENCES: SUPERLATIVES}

1. The latest $333 \mathrm{MHz}$ Intel Pentium Processor lets your PC perform better.

True - False

2. The Nec's fastest available microprocessor allows you to run multiple applications simultaneously.

True - False

3. Running the latest, greatest, hottest, most challenging of all software programs is not important.

True - False

B. Be ready to share your answers with the rest of the class.

C. Individual work. Look at the boldface words in the previous exercise and answer the following questions.

1. Which words use est?

2. When is the most used?

3. Notice: good and the best bad and the worst

D. Share your answers with the rest of the group. 
V. Read the following sentences. Pay attention to the underlined information.

1. Pentium IV is the fastest processor available.

2. WordPad is the easiest program you can use to type documents.

3. Hewlett Packard sells the most expensive laser printers.

4. The mouse is one of the cheapest devices of your computer system.

5. Microsoft is the most important software company in the world.

6. Anthrax is one of the most dangerous computer viruses on the net these days.

7. Norton is one of the best anti-viruses you can install on your system.

\section{POST-TASK}

\section{GRAMMAR PRACTICE: SUPERLATIVE FORM}

Individual work. Complete the following short conversations with the superlative form of the adjectives in parentheses.

1. A: Which processor is (fast) , Pentium 2, 3 or 4 ?

B: Pentium 4 is (fast) computer processor you can buy.

2. A: Which brand is (expensive) Hewlett Packard, Epson or IBM?

B: I think Hewlett Packard is (expensive) brand.

3. A: Which processor is (good) Athlon, Celeron or Pentium?

B: In my opinion, Pentium is (good) processor.

4. A: Which program is (difficult) , Windows XP, Windows Millenium or Windows Vista?

B: I believe Windows XP is (easy) work with. environment you can

5. A: Which computer is (big) computer or a laptop computer? , a pocket PC, a desktop

B: A pocket $\mathrm{PC}$ is (small) computer available. 


\section{Comments on the Lesson}

The sample lesson presented in this article was designed to help learners understand and use the superlative form of adjectives in English using a more innovative methodology, the Task-based approach, than the traditional way. Students were given a series of activities to help them infer the rule of the superlative form of adjectives in English. Some of these activities were answering questions, discriminating between true and false sentences and reading advertisements and sentences. These exercises were done in pairs or individually, both orally and in a written way. In this lesson, the role of the learners was very active and autonomous, and that of the instructors was to guide and monitor the students' work. In other words, the main role of the instructors was to help learners only if they required so.

It is important to mention that when the lesson was over, the main objective of the lesson had been achieved since the students had come up with the rule of the superlative form of adjectives in English. Students were motivated and proud of having done the task on their own, only with the help of the materials given to them and the help of their partners'.

\section{Recommendations and Conclusions}

Before including task-based instruction in an ESP context, course designers should take into account these recommendations:

1. Integrate different language skills within the $T B L$ framework.

2. Use authentic materials (oral or written) to design the lesson.

3. Expose learners to comprehensible and meaningful input.

4. Avoid adapting or modifying authentic materials to decrease their level of difficulty.

5. Help learners solve the tasks at their own pace.

6. Consider learners' background knowledge on the topic to be studied.

7. Try to keep learners' motivation high.

8. Identify and select target tasks during the needs analysis stage of creating the general and specific objectives of the ESP course.

9. Identify and select pedagogical tasks that correlate with those activities ESP students must carry out at their workplace.

10. Correct students' production.

11. Provide feedback on students' mistakes. 
Language teachers should pay attention to this list of suggestions since TBL does not share the same characteristics of traditional grammar-based methodologies even though they are included in communicative methods or approaches. For instance, instructors must consider that this approach seems to work more effectively with small groups of students while teachers are constantly monitoring their work; however, they must not interfere at all times. By doing so, learners can have the possibility to interact more among themselves. If the level of difficulty of the reading texts is high, students may use a dictionary to facilitate comprehension. Furthermore, in an ESP context, teachers should always take advantage of the knowledge and experience that students bring to class so that they generate their own ideas. It is important to keep a record of the students' performance while doing the different stages of the framework to make possible changes to the lesson in order to improve course materials. This can be achieved by videotaping the lesson or keeping a journal to reflect on the effectiveness of the lesson and its materials. If all these recommendations are followed, teachers can be able to create more appealing, motivating and challenging ESP materials, but they need to evaluate students' outcome and performance once the activities have been carried out.

To conclude, it is important to point out that implementing the TBL methodology in an ESP context is a challenging task for language teachers. In fact, finding appropriate materials (i.e. newspaper or magazine ads) is time consuming due to the fact that instructors have to obtain samples of authentic discourse for the learners; thus, they can use them during the different stages of the lesson. In task-based instruction, as Brown (1994, p. 229) points out, the priority is not the bits and pieces of language but rather the functional purpose for which language must be used. Consequently, when deciding to use TBL, instructors have to be seen as motivators and facilitators of the learning process since the idea is to make learners responsible for their own learning, and as a result, autonomy must be favored when using this approach. Obviously, teachers should take advantage of different approaches and techniques and combine them to help learners improve their skills. As a result, by implementing task-based instruction, learners as well as teachers will certainly benefit from a different approach to language pedagogy because it is more motivating, more challenging, more innovative, more appealing and more meaningful to students than other traditional grammar-based approaches. 


\section{References}

Brown, H. Douglas. (1994). Teaching by Principles: An Interactive Approach to Language Pedagogy. N.J.: Prentice Hall Regents.

Carter, Ronald and Nunan, David (Eds.) (2001). Teaching English to Speakers of Other Languages. United Kingdom: Cambridge University Press.

Celce-Murcia, Marianne and Olshtain, Elite. (2000). Discourse and Content in Language Teaching: A guide for Language Teachers. U.K.: Cambridge UP.

Ellis, Rod. (2006). The Methodology of Task-Based Teaching. Asian EFL Journal, 8 (3). Retrieved January 9, 2009, from http://www.asian-efljournal.com/September 06 home.php.

Willis, Jane. (1996). A Framework for Task-based Learning. Oxford: Longman.

Willis, Jane. (1998). Task-Based Learning: What Kind of Adventure? Retrieved January 9, 2009 from http://www.jalt-publications.org/ttt/files/98/jul/willis.html.

Ziff David Media. (2001). PCMagazine. New York: Ziff Davis Publishing Holdings. 